\title{
Participatory development of a care line for workers with Repetitive Strain Injury
}

\author{
Construção participativa de uma linha de cuidado ao trabalhador com Lesão por Esforços \\ Repetitivos
}

Amélia Romana Almeida Torres ${ }^{1}$, Ivana Cristina Holanda Cunha Barreto², Izabelle Mont'Alverne Napoleão Albuquerque $^{3}$, Valéria Bastos Gomes ${ }^{4}$

Objective: to build an integral care line for workers with repetitive strain injuries. Methods: action-research with actions of the care line were developed in four workshops with the participation of 32 professionals, managers and users of primary, secondary and tertiary healthcare. Actions which obtained $80.0 \%$ agreement of the participants were included in the care line. Results: the Family Health Strategy was defined as the main gateway, coordinating and organizing the care through surveillance of workers' health in its territory. As a secondary gateway, in urgent cases, referral hospitals were cited. The specialized care network was responsible for diagnosis, treatment and rehabilitation of referred cases. Conclusion: the care line developed by the action-research allowed the visualization of a flow to attention to workers and can be a reference for other municipalities.

Descriptors: Occupational Health; Health Services; Cumulative Trauma Disorders.

Objetivo: construir uma linha de cuidado integral para o trabalhador com lesões por esforços repetitivos. Métodos: pesquisa-ação com ações da linha de cuidado foram construídas em quatro oficinas, com a participação de 32 profissionais, gestores e usuários da atenção primária, secundária e terciária. Foram incluídas na linha de cuidado as ações que obtiveram 80,0\% de concordância dos participantes. Resultados: a Estratégia Saúde da Família foi definida como principal porta de entrada, coordenadora e ordenadora do cuidado e pela vigilância à saúde do trabalhador no seu território. Como porta de entrada secundária, em casos de urgência, ficaram hospitais de referência. A rede de atenção especializada ficou responsável pelo diagnóstico, tratamento e reabilitação de casos referenciados. Conclusão: a linha de cuidado construída pela pesquisa-ação permitiu a visualização de um fluxo para atenção aos trabalhadores e pode ser referência para outros municípios.

Descritores: Saúde do Trabalhador; Serviços de Saúde; Transtornos Traumáticos Cumulativos.

\footnotetext{
${ }^{1}$ Instituto Superior de Teologia Aplicada. Sobral, CE, Brazil.

${ }^{2}$ Universidade Federal do Ceará. Sobral, CE, Brazil.

${ }^{3}$ Universidade Estadual Vale do Acaraú. Sobral, CE, Brazil.

${ }^{4}$ Fundação Oswaldo Cruz. Fortaleza, CE, Brazil.
} 


\section{Introduction}

Building care lines in the Unified Health System entails the establishment of safe flows to all services that meet the full needs of users. In addition to the flows, the health work in the care line should include articulated participation and knowledge, practices and looks of a multidisciplinary team, seeking to ensure comprehensive care ${ }^{(1)}$.

In this process, the implementation of the Care line allows organizing and coordinating resources in the different points of attention to ensure access and comprehensive care, establishing the assistance route, organizing the flow of individuals according to their needs, and establishing the roles and responsibilities of each service in the production of health, providing a common language in the various care networks ${ }^{(2)}$.

The present research focuses on the care line in attention to the worker's health that seeks to approach and intervene in the relationship between work and health/disease process. The intra-sectoral integration in health is weak and discontinuous at some levels of care $^{(3)}$, particularly in primary care and emergency services. It does not establish relations between the grievance and labor, and this hinders the adoption of procedures for prevention, cure and rehabilitation for the solution of the problem.

In this sense, the National Network of Comprehensive Care for Workers' Health, whose purpose is to strengthen coordination within the National Health System, strengthen the promotion, prevention, protection, surveillance and recovery of the health of urban and rural workers, guides the creation of lines of care for each hazard to workers' health. In this context, it is the municipalities' responsibility to propose reference flows and counterreference in each care line ${ }^{(4)}$.

The axis integrating the National Network of Comprehensive Care for Workers' Health is the regionalized network of Worker's Health Reference
Centers, consisting of state and regional centers, managed by the state or the municipality and located in metropolitan areas and municipalities that are the base of assistance centers of regions and microregions of health ${ }^{(4)}$.

Among the diseases that affect workers, repetitive strain injuries and musculoskeletal disorders related to work stand out. These diseases are caused by excessive use imposed on the musculoskeletal system by determined efforts at work and lack of time for recovery of these structures. They are characterized by the occurrence of various symptoms, concomitant or not, such as pain, numbness, heaviness and fatigue. The disease is insidious and usually affects the upper $\operatorname{limbs}^{(5)}$.

Public recognition of repetitive strain injuries and musculoskeletal disorders related to work, such as pathology associated with working conditions, brings out a tip of an iceberg: diseases associated with self-aggressive conditions of work that affect the everyday activities and generate concern and distress in the people affected ${ }^{(6)}$. In Brazil, registered epidemiological data do not reflect the total number of employees, but refer only to formal workers, which represent less than $50.0 \%$ of the economically active population $^{(7)}$.

Whereas this new conception of the health of the worker with these types of injuries and disorders related to work is still being introduced into the health system, the present study aimed to develop a full care line for workers with repetitive strain injuries.

\section{Methods}

This research drew a methodological approach that allowed the participation of health professionals, managers and users in a set of joint planning of propositions and actions related to the health of workers, aimed at sowing changes in the municipal context. We opted for action-research because this is 
a methodology that aims at the practice/action and promotes awareness and the ability to transform reality through the research subjects ${ }^{(8)}$.

As part of the action-research strategy, it was decided also to held workshops in a constructivist perspective, understanding that both the subject and its socio-historical characteristics need to be contextualized as an object of study, implying questioning the reality for solving the problem studied $^{(9)}$. Transforming action strategies such as technology of the care line were used to facilitate the search for solutions to problems for which conventional procedures have not been effective.

The survey was conducted in the city of Sobral, located in the Northwest region of Ceará, Brazil. The study was carried out in the period of November 2012 to January 2013. The Municipal Health System consists of a network of primary, secondary and tertiary care services, insured or contracted, serving a population of approximately 1,600,000 inhabitants of the north of the state. The service is a reference to five health regions of the Northwest of Ceará(10).

In 2010, the Sentinel Services Network for Worker's Health was implemented in Sobral. Since then, the Notification of Diseases in Worker's Health was included in the service routine. In 2010, eight cases of Repetitive Strain Injury and musculoskeletal disorders were reported; in 2011, 68 cases; and in 2012, 50 cases corresponding to a rate of detection of cases of respectively $9.5,80.7$ and 59.3 per 100,000 inhabitants.

For selection of research participants, criteria adopted were the representation of professionals and managers of the various health services of the network that assist workers with repetitive strain injuries and musculoskeletal disorders related to work. The selection of participants was intentional, and calls were made through phone and email messages. The inclusion criteria are shown in Figure
1 , and participants amounted to 32 subjects.

The care line for workers affected by repetitive strain injuries and musculoskeletal disorders related to work, containing the definition of the gateways, of the flows and of the responsibilities of the professionals of the support network, was developed after four workshops with the group. The workshops took place in the Worker's Health Reference Center, lasted four hours and included the participation of 32 managers, health professionals and users.

The first workshop consisted of a moment of reflection, emphasizing the need for comprehensiveness in the attention to the health of the worker with repetitive strain injuries and musculoskeletal disorders related to work. The following questions were raised: how is the attention to the worker realized within the Unified Health System network? Who assists the worker? In the sequence, participants started the discussion by pointing out some services involved and some actions taken, but ignorance about the actual flow that the worker has to go through within the network became clear in the debate, as well as uncertainties about the tasks of each health unit. Thus, the researcher asked again: Does comprehensive care to workers with repetitive strain injuries and musculoskeletal disorders related to work happen within the Unified Health System service network? How to improve the attention given to the worker in the Unified Health System?

In the second workshop, the goal was to map the opportunities that the user has to access the Unified Health System network that serves/assists this worker. In this workshop, a case study of a worker with the disease was used, leading the group to reflect based on a real situation. The group was invited to fill a matrix according to the context of the municipal health network, identifying the services that meet the worker with repetitive strain injuries and musculoskeletal disorders related to work (Figure 1). 


\begin{tabular}{|c|c|c|c|c|c|c|c|c|}
\hline \multirow[b]{2}{*}{ Segment } & \multirow[b]{2}{*}{ Selection criterion } & \multicolumn{7}{|c|}{ Participants } \\
\hline & & Manager & Physician & Nurse & $\begin{array}{c}\text { Physio- } \\
\text { therapist }\end{array}$ & $\begin{array}{c}\text { Psycho- } \\
\text { logist }\end{array}$ & $\begin{array}{l}\text { Community } \\
\text { Health Agent }\end{array}$ & User* \\
\hline $\begin{array}{l}\text { Professionals of the Family } \\
\text { Health Teams }\end{array}$ & $\begin{array}{l}\text { Teams that reported most cases } \\
\text { in } 2012\end{array}$ & - & 2 & 2 & - & - & 5 & - \\
\hline $\begin{array}{l}\text { Professionals of the team of the } \\
\text { Family Health Support Center }\end{array}$ & $\begin{array}{l}\text { Team of the Family Health Sup- } \\
\text { port Center that most reported } \\
\text { cases in } 2012\end{array}$ & - & - & - & 1 & 1 & - & - \\
\hline $\begin{array}{l}\text { Professionals of the Multidis- } \\
\text { ciplinary Residency in Family } \\
\text { Health }\end{array}$ & $\begin{array}{l}\text { Team that most reported cases } \\
\text { in } 2012\end{array}$ & - & - & 1 & - & - & - & - \\
\hline Users & $\begin{array}{l}\text { Workers with repetitive strain } \\
\text { injuries and musculoskeletal } \\
\text { disorders related to work assist- } \\
\text { ed at the Reference Center for } \\
\text { the Worker's Health }\end{array}$ & - & - & - & - & - & - & 3 \\
\hline $\begin{array}{l}\text { Managers of the Municipal } \\
\text { Secretariat of Health }\end{array}$ & $\begin{array}{l}\text { Coordinators of Primary, Sec- } \\
\text { ondary and Tertiary Health Care } \\
\text { and Surveillance }\end{array}$ & 3 & - & - & - & - & - & - \\
\hline $\begin{array}{l}\text { Specialized services that assist } \\
\text { and notify cases of workers with } \\
\text { repetitive strain injuries and } \\
\text { musculoskeletal disorders relat- } \\
\text { ed to work. }\end{array}$ & $\begin{array}{l}\text { Professionals that assist work- } \\
\text { ers with repetitive strain inju- } \\
\text { ries and musculoskeletal disor- } \\
\text { ders related to work }\end{array}$ & 2 & 3 & 3 & 2 & - & - & - \\
\hline $\begin{array}{l}\text { Urgency and emergency services } \\
\text { that assist and notify repetitive } \\
\text { strain injuries and musculoskel- } \\
\text { etal disorders related to work. }\end{array}$ & $\begin{array}{l}\text { Professionals that assist work- } \\
\text { ers with repetitive strain inju- } \\
\text { ries and musculoskeletal disor- } \\
\text { ders related to work }\end{array}$ & - & 1 & 2 & - & - & - & - \\
\hline $\begin{array}{l}\text { Intersectoral Commission on } \\
\text { Worker's Health }\end{array}$ & Representative & 1 & - & - & - & - & - & - \\
\hline \multicolumn{2}{|l|}{ Total participants by category } & 6 & 6 & 8 & 3 & 1 & 5 & 3 \\
\hline
\end{tabular}

Figure 1 - List of participants according to the segment and selection criteria. $n=32$

The third workshop, with 32 participants, aimed to define the duties of professional services that assist workers, seeking comprehensive care. In this moment, the same techniques of the second workshop were used, but further content was presented in Power Point $^{\circledR}$, as for example the Decree $n^{0}$ 1,323/2012 of the Ministry of Health, establishing the Occupational Health National Policy and Working ${ }^{(4)}$. It was also presented the flow chart of service standardized by the Ministry of Health in the protocol of pain related to work. Then, the same study of the first workshop was presented and the following question was asked to participants: which assignments of the Primary Health Care, the Specialized Care and Emergency Department are necessary to ensure full assistance to the worker with repetitive strain injuries and musculoskeletal disorders related to work? The researcher asked participants to describe the practices that the professionals of care networks develop or should develop during the work routine to ensure comprehensive care focused on workers.

The workshops were recorded in written reports. Subsequently, the same researcher performed 
the analysis of the assignments mentioned, eliminating repetitions, systematizing and grouping similar information, and building an array of Care line for Workers with Repetitive Strain Injuries. This systematization was reviewed by a second researcher. The fourth workshop aimed to present and validate the proposed care line with all participants of the action-research.

After the presentation, it was explained to the group how would the process of material validation happen and the importance of each participant point the degree of agreement or disagreement for each of the assignment set by the group. We used a scale ${ }^{(11)}$ to measure the degree of agreement among participants. The scale has five response categories. Participants are instructed to select only one alternative, according to the degree of agreement or disagreement. The alternative 1 means complete disagreement and 5 means total agreement. The responses of participants registered in a form were entered into an Excel spreadsheet, and simple frequency of the evaluations of participants for each assignment was calculated. Items that obtained total or partial agreement (4 or 5) for at least $80.0 \%$ of workshop participants were definitely included in the Care line.

The study complied with the formal requirements contained in the national and international regulatory standards for research involving human beings.

\section{Results}

One of the objectives of the proposed care line was to establish the assistance route, in order to organize the flow of these workers according to the needs presented and to ensure comprehensive care. Services providing care to workers' health in Sobral, Brazil, are described in Figure 2.

\begin{tabular}{|l|l|}
\hline Care network & $\begin{array}{l}\text { Health care services to workers with } \\
\text { repetitive strain injuries and musculo- } \\
\text { skeletal disorders related to work }\end{array}$ \\
\hline Primary Health Care & $\begin{array}{l}\text { Family Health Strategy, Family Health } \\
\text { Center and Multidisciplinary Residency. }\end{array}$ \\
\hline $\begin{array}{l}\text { Specialized, outpatient } \\
\text { and rehabilitation ser- } \\
\text { vices. }\end{array}$ & $\begin{array}{l}\text { Medical Specialties Center, Physical Reha- } \\
\text { bilitation Center, Polyclinic and Worker's } \\
\text { Health Reference Centers. }\end{array}$ \\
\hline $\begin{array}{l}\text { Attention to urgency and } \\
\text { emergency }\end{array}$ & $\begin{array}{l}\text { Northern Regional Hospital and Municipal } \\
\text { Referral Hospital (Santa Casa de Sobral) }\end{array}$ \\
\hline
\end{tabular}

Figure 2 - Composition of the healthcare services part of the care line to workers with repetitive strain injuries and musculoskeletal disorders related to work

Opportunities to access health services were identified. It was pointed out that workers can find various services of the care network. Among these, as a main gateway, is the Primary Health Care, including: the Family Health Strategy, the Family Health Support Center and the Multidisciplinary Residency in Family Health. In Specialized Care, the Medical Specialties Center, the Physical Rehabilitation Centre and the Polyclinic. The Regional Reference Center in Worker's Health was included in the specialized network, but its functions appear prominently, because this is a service of surveillance also. In attention to Urgency and Emergency, two hospitals (Figure 2) were identified.

Figures 1 and 2 show the care line ${ }^{(12)}$ developed and this is a representation of the flows of production of assistance and the synthesis of the duties of professionals and care network services in relation to the worker with repetitive strain injuries and musculoskeletal disorders.

Figures 3 and 4 show the care line developed, adapted from the described fluxogram ${ }^{(13)}$. 
1. Mapping of productive activities and identification of risks related to work; 2 . Recognition of users as a workers and establishment of the relationship between the complaints and symptoms to work; 3 . Recognition of the workers with increased risk and referral to support services; 4. Realization of articulated reference and counter reference within network services; 5. Monitoring of the worker at all stages of treatment; 6. Realization of educational activities; 7. Development of support and self-care groups to workers with the disease; 8. Use of epidemiological information as base for the promotion, prevention, treatment and rehabilitation; 9. Incorporation of the theme in moments of open discussion, training and continuing education; 10. Liaison with the Reference Center staff to provide specialized technical backing; 11. Notification of Diseases in the system.

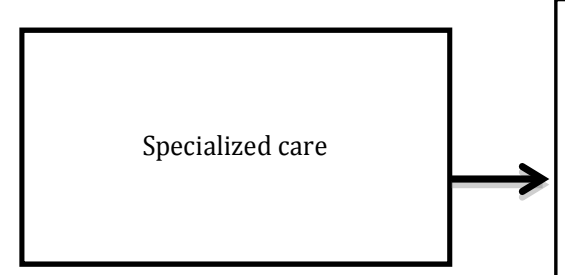

1. Assistance to the worker and identification of complaints related to work by the user; 2 . Conducting host, diagnosis, treatment, and laboratory tests; 3. Notification of the disease in System of Notification of Diseases; 4.Guidance about performing daily life activities and self-care; 5. Reference and counter-reference of workers for purposes of continuity of care; 6 . Filling the medical examination report of the work accident when appropriate; 7. Conducting matricial actions in Primary Care; 8. Actioning the Reference Center team whenever necessary for the provision of specialized technical backing; 9. Incorporation of the theme in training strategies and continuing education; 10. Conducting physical rehabilitation of workers (specific to the rehabilitation service).

Figure 3 - Synthesis of the care line for the health of workers with repetitive strain injuries and musculoskeletal disorders in primary health care and specialized care

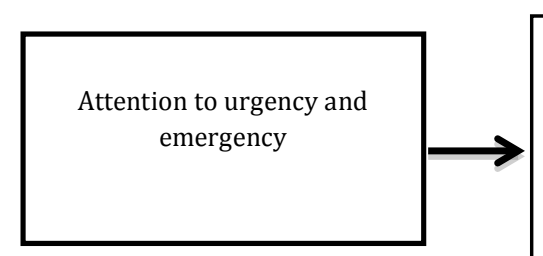

1. Assistance to workers in case of urgent grievances identifying the complaint associated by the user with the work; 2. Filling the medical examination report of the work accident when appropriate; 7. Notification of the disease in the System of Notification of Diseases; 4. Conducting counter-reference to continue the treatment, monitoring and rehabilitation; 5. Articulation of the Reference Center team in Worker's Health for the provision of specialized technical backing..

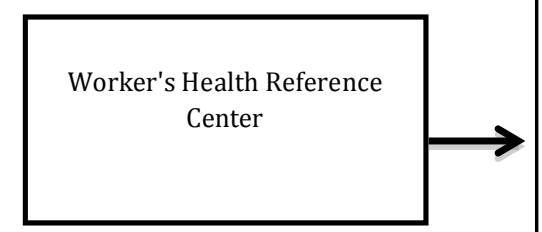

1. Provision of assistance to the worker in an interdisciplinary, conducting detailed occupational history; 2. Identification of the relationship between work and illness and notification in the System of Notification of Diseases; 3. Articulation of the network of intersectoral and intra-sectoral support for resolution of more complex cases; 4. Matrix support to network services in times of permanent education and promotion, prevention, diagnosis, treatment, reporting and monitoring; 5. Conducting surveillance actions in workplaces in production processes that offer risks based on priorities; 6 . Analysis and dissemination of epidemiological information to give base to actions of attention to Worker's Health; 7. Conducting health education activities; 8. Systematization and analysis of information of the mapping to support workers' health actions to the needs identified in the territories; 9. Professional training; 10. Filling the medical examination report of the work accident when appropriate.

Figure 4 - Synthesis of the care line for the health of workers with repetitive strain injuries and musculoskeletal disorders in attention to Urgency and Emergency and in the Worker's Health Reference Center 


\section{Discussion}

Among the limitations of this study, it is noteworthy that the care line presented cannot be generalized to Brazil because the services presented in this study have settings that can be very different from the reality of other municipalities. However, the care line constructed can function as a template for the municipality and/or the region with adjustments.

Although the care line is considered an ideal model of social assistance, with a view to comprehensiveness, evaluative studies showing the impact of organizational arrangement in the quality of health care provided for the population are still necessary. Further future works may complement the present results, especially regarding the need for more actions and tools for realization of comprehensive care.

After observing the limitations of this study, it is emphasized that this line runs the risk of flows and assignments presented be disrupted and fragmented. This is because the proposal of the line was developed, but who in fact defines the profile of this care are the professionals who serve users and that do and decide how this line will work in everyday life. In order to turn this line effective, collaboration between management, workers and users is also fundamental. Discussions for implementation of this care line started during the campaign about Repetitive strain injuries and musculoskeletal disorders. One of the actions of the campaign involved the presentation and debate of the care line in a conceptual theoretical moment with the managers of the Family Health Centers. As result of this moment, it was suggested to carry out an activity of continuing education on the topic for family health teams. In this activity, the care line strategies would be present and worked for their enforcement. It is believed that this moment was a key step because the professionals of family health teams are the ones that dialogue with all services, in a scenario of diversity, creating possibilities, opening paths, seeking alternatives and establishing dialogues with other services the Unified Health System and the management.

It is also important to note the role of managing to facilitate dialogue between services, supply and provide structures with sufficient resources so that this line succeed. Therefore, a meeting with the Secretary of Health, coordinators and managers of the municipal administration and the municipal health board is suggested for presentation of the care line and for agreement of actions to be implemented for the development and execution of the care line for repetitive strain injuries and musculoskeletal disorders related to work in the municipality.

The following assignments to the professionals of the Family Health Strategy emerged from the present action-research: to follow the worker at all stages of the treatment of repetitive strain injuries and musculoskeletal disorders related to work, seeking comprehensive care; to develop self-care and support groups to the affected workers; to carry out educational activities with the workers of its territory to help preventing these injuries and to use epidemiological information to guide the actions of promotion, prevention, treatment and rehabilitation. Others are listed in Figures 3 and 4.

In a literature review that examined articles and normative documents to identify actions of health care to the worker by the teams of Primary Health Care, six groups of actions ${ }^{(12)}$ were organized: a) diagnosis of the situation, including the identification of productive activities; b) characterization of the demographic and epidemiological profile of workers; c) planning of actions to prioritize interventions for the health problems with higher frequency, risk and vulnerability; d) assistance to the worker victim of an accident or work-related disease; e) educational actions and actions for health promotion; f) actions characterized as Worker's Health Surveillance. In this review $^{(14)}$, the authors discussed the potentials and limitations of Primary Health Care to develop actions and recommended the promotion of lifelong learning and matricial actions by Worker's Health Reference 
Centers. These functions are very similar to the assignments listed by the participants of the present action-research, and as a result of the participation of service professionals, the assignments of primary health care are described in more direct and detailed manner, so as to guide the operation. However, some actions identified for Primary Care in the bibliographic and documentary review were not clearly selected as assignment of primary care in the present study, such as assistance to occupational accidents. This may be understandable because, thinking in terms of care line, this assignment has been identified as belonging to urgency and emergency services of Sobral, Brazil, by the research participants.

In an international publication, the importance of integrating occupational health actions in the everyday activities of professionals of the primary health care is also noted, emphasizing the training of professionals to gain skills and to recognize health problems related to work in early moments, as well as to advice on how to improve working conditions. Also important, the primary care should be integrated with other health services to improve attention to workers $^{(14)}$.

In specialized care, basically the same assignments defined in the Worker's Health National Policy ${ }^{(4)}$ were identified with greater detail and use of different terms (Figure 3). Specific assignments for the Worker's Health Reference Center (Figure 4) were also listed. The attention to the worker's health becomes mutual responsibility in a logic that integrates actions of care, surveillance, individual and collective intervention, as it is advocated to achieve comprehensiveness in the Unified Health System ${ }^{(15)}$.

The information on the profile of workers obtained by mapping the territory and of the survey of the epidemiological profile of work-related diseases ia key to the plan activities and give visibility to problems, making the worker health disorders come on the agenda of professionals of the Primary Health Care $^{(12)}$. In order that the primary health care may actually coordinate comprehensive care to workers' health, the collaboration of other network services is essential to ensure the correct diagnosis, to define and properly implement the care plan. Furthermore, the worker must be instructed as to the evolution of the disease, carrying out activities of daily life, prevent further damage and its rights ${ }^{(12,16)}$. The formation of rehabilitation groups is also of fundamental importance, since it helps in driving better treatment of repetitive strain injuries and musculoskeletal disorders related to work.

Educational activities are part of the day-today of teams, and they need to incorporate the theme Worker's Health in their daily practices. There are several educational activities that can be developed, among which is worth to mention guidelines on the working environment and its risks, labor rights, care of the injury or situation of exposure, guidelines on the line care and flows that the worker should follow in the event of illness, among others.

Other activities that should be strengthened are matricial actions, ensuring the technical and pedagogical support for teams of Primary Health Care through care services specialized in worker's health so that they can plan their activities, considering the productive profile and the health condition of workers. This matricial support is a challenge because it is essential that people carrying it out assume the care in collaboration with the teams of Primary Health Care, sharing experiences and knowledge to build new health practices and allowing worker's health issues come on the agenda of professionals of the Family Health Strategy.

The formation of rehabilitation groups is also of fundamental importance, since it helps in driving better treatment of repetitive strain injuries and musculoskeletal disorders related to work. These activities assist in empowerment of the worker through knowledge and information on the relationship of the health disease process related to work.

Understanding the relationship between work and health, in an interdisciplinary perspective, is one of the worker's health pillars. It is important 
to rearrange the work in health and to incorporate matricial actions with the creation of collective spaces for active communication, knowledge sharing and interaction. Interdisciplinary work improves communication among professionals, circulation of information and knowledge, in addition to allowing the exchange and co-responsibility ${ }^{(15)}$.

The literature shows that the organization of the assistance provided to the worker's health care, beginning with Primary Health Care, is of particular importance when considering the capillarity of the system, the possibility of a comprehensive health care to get as close to where people live and work, and the potential of these services to identify the health needs of the population in the territory related to productive activities, and, with this information, plan and execute actions $^{(17)}$.

\section{Conclusion}

Participatory construction of the care line for workers with Repetitive strain injuries and musculoskeletal diseases in the network health services of the Unified Health System of Sobral, Brazil, established the Family Health Strategy as a main gateway, coordinating and ordering care with Family Health Support Centers. For the Family Health Strategy, it was also given the assignment to develop surveillance of workers' health in the territory and to develop the main actions of prevention and promotion of workers' health. As a secondary gateway, in cases of urgencies, were cited the Northern Regional Hospital and the Santa Casa de Sobral. The specialized care network was responsible for hosting referenced cases, diagnosis, treatment, complementary tests and more specialized actions for rehabilitation. To the Workers' Health Reference Center was attributed, in addition to the diagnosis and treatment of the most complex cases, the collection, storage and analysis of information on workers' health.

We must recognize that establishing a care line is insufficient to ensure qualified health care to workers. Effective management, adequate infrastructure, equipment, qualified human resources, and information systems and logistics are also required. However, the care line built in this actionresearch represents one additional tool to assist in the execution of comprehensive care to workers' health with Repetitive strain injuries and musculoskeletal disorders, and can be used as a reference for other municipalities and regions.

\section{Acknowledgements}

To the Coordination for the Improvement of Higher Education Personnel for the financial support through the Research Laboratory for Education and Knowledge Management, Education and Work in Health, Case no 0363163.

\section{Collaborations}

Torres ARA, Barreto ICHC, Albuquerque IMN and Gomes VB participated in the project conception and design, collection and analysis of data, critical writing and analysis of the article and final approval of the version to be published.

\section{References}

1. Malta DC, Merhy EE. O percurso da linha do cuidado sob a perspectiva das doenças crônicas não transmissíveis. Interface Comunic Saude Educ. 2010; 14(34):593-605.

2. Mendes EV. Organização Pan-Americana da Saúde. As redes de atenção à saúde. Brasília: OPAS; 2011.

3. Lacerda e Silva T, Dias EC, Pessoa VM, Fernandes LMM, Gomes EM. Occupational health in primary care: perceptions and practices in family health teams. Interface Comunic Saúde Educ. 2014; 18(49):273-87.

4. Ministério da Saúde (BR). Portaria n. 1.823/GM, de 23 de agosto de 2012. Institui a Política Nacional de Saúde do Trabalhador e da Trabalhadora. Brasília: Ministério da Saúde; 2012. 
5. Al-Eisa E, Buragadda S, Shaheen AAM, Ibrahim A, Melam GR. Work related musculoskeletal disorders: causes, prevalence and response among egyptian and saudi physical therapists. Middle-East J Sci Res. 2012; 12(4):523-9.

6. Rodrigues BC, Moreira CCC, Triana TA, Rabelo JF, Higarashi IH. Limitation an consequences caused by work-related diseases in the worker's lives. Rev Rene. 2013; 14(2):448-57.

7. Ministério da Saúde (BR). Secretaria de Vigilância em Saúde. Departamento de Vigilância em Saúde Ambiental e Saúde do Trabalhador. Dor relacionada ao trabalho: lesões por esforços repetitivos (LER): Distúrbios Osteomusculares Relacionados ao Trabalho (DORT). Brasília: Ministério da Saúde; 2012.

8. Thiollent M. Metodologia da pesquisa-ação. São Paulo: Cortez; 2011.

9. Spink MJ. Linguagem e produção de sentidos no cotidiano [Internet]. 2010 [citado 2015 nov 26]. Disponível em: http://static.scielo.org/scielobooks/w9q43/pdf/spink-9788579820465.pdf

10. Secretaria da Saúde e Ação Social de Sobral (CE). Plano municipal de saúde competência 20092013. Sobral: Secretaria da Saúde; 2013.

11. Dalmoro M, Vieira KM. Dilemas na construção de escalas tipo Likert: o número de itens e a disposição influenciam nos resultados? Rev Gestão Organizacional. 2013; 6(3):161-74.
12. Dias EC, Lacerda e Silva T. Contribuições da Atenção Primária em Saúde para a implementação da Política Nacional de Saúde e Segurança no Trabalho (PNSST). Rev Bras Saude Ocup. 2013; 38(127):31-43.

13. Franco TB, Merhy EE. Cartografias do trabalho e cuidado em saúde. Tempus Actas Saude Coletiva. 2012; 6(2):151-63.

14. Rafiei M, Ezzatian R, Farshad A, Sokooti M, Tabibi R, Colosio C. Occupational health services integrated in primary health care in Iran. Ann Global Health. 2014; 81(4):561-7.

15. Santos APL, Lacaz FAC. Apoio matricial em saúde do trabalhador: tecendo redes na atenção básica do SUS, o caso de Amparo/SP. Cienc Saúde Coletiva. 2012; 17(5):1143-50.

16. Dias EC, Hoefel MG. Desenvolvimento das ações de saúde do trabalhador no SUS: A estratégia da rede nacional de atenção integral a Saúde do trabalhador (RENAST). In: Gomez CM, Machado JMH, Pena PGL, organizadores. Saúde do trabalhador na sociedade Brasileira Contemporânea. Rio de Janeiro: FIOCRUZ; 2011. p.107-22.

17. Dias EC, Ribeiro EEN, organizadores. Secretaria de Estado da Saúde de Minas Gerais. Construindo ações de Saúde do Trabalhador no âmbito das Superintendências e Gerências Regionais de Saúde. Belo Horizonte: Minas Gerais; 2011. 